\title{
Liver Hydatid Cyst Associated With Biliary Tract: Is it An Important Complication Indicator?
}

\author{
Ulas Aday $^{\mathrm{a}}$, Murat Kapan ${ }^{\mathrm{a}}$, Akin Onder ${ }^{\mathrm{a}}$, Zulfu Arikanoglu, ${ }^{\mathrm{a}, \mathrm{b}}$, Ibrahim Aliosmanoglu ${ }^{\mathrm{a}}$, \\ Mesut Gula , Ibrahim Halil Tacyildiz ${ }^{\mathrm{a}}$
}

\begin{abstract}
Background: Hydatid cyst disease is a zoonotic disease caused by echinococccus granulosus. We aimed to investigate the relation between cyst location, size, laboratory values and presence of intracavitary bile duct, and also the effects of surgical procedures.
\end{abstract}

Methods: Between March 2005 and January 2010, 100 patients who underwent surgery for hydatid cyst were reviewed retrospectively.

Results: The patients included 63 women and 37 men. The mean age was 35.6 years. A series of 134 cysts were determined in 100 patients. Partial cystectomy and drainage were applied in 88, laparoscopic drainage in 7 , and total cyst excision in 5 patients. Intraoperatively, cysts associated with bile duct were found in 48 patients. The mean cyst size was $11.8 \mathrm{~cm}$ in the patients with cysts associated with biliary tract and $8.6 \mathrm{~cm}$ in the others. Preoperative aspartate aminotransferase (AST), alkaline phosphatase (ALP) and gammaglutamyl transferase (GGT) values were higher in the patients with cysts associated with bile duct. The most common complications were biliary fistula and cavitary infection. The rate of major complication was $50 \%$, and the mean hospital stay was 17.48 days in the patients with cysts associated with bile duct, while in the others they were $15.4 \%$ and 8.46 days, respectively.

Conclusions: Large cysts and higher values of AST, ALP and GGT were related with the presence of intracavitary bile ducts. While the surgical techniques and cysts' localization and stage had no effects,

Manuscript accepted for publication December 12, 2011

${ }^{\mathrm{a}}$ Department of Surgery, Dicle University Faculty of Medicine, 21280, Diyarbakir, Turkey

${ }^{b}$ Corresponding author: Zulfu Arikanoglu, Department of Surgery, Dicle University Faculty of Medicine, 21280, Yenisehir, Diyarbakir, Turkey.

Email: zulfuarikanoglu@gmail.com

doi: $10.4021 / \mathrm{jcs} 5 \mathrm{w}$ cysts associated with bile duct led to higher complication rates and longer hospital stays.

Keywords: Liver hydatid cyst; Complications; Bile duct

\section{Introduction}

Hydatid cyst disease, introduced by E. Granulosus, is a parasitic disease which is possible in any organ or tissue but more commonly in liver and lungs [1]. It is endemic in the Mediterranean countries, South America, the Far East, the Middle East, and Eastern Europe [2]. The disease may remain asymptomatic for many years [3]. When it becomes evident, it leads to various symptoms, in which the most common ones are abdominal pain and hepatomegaly. The most common complication is the rupture into intrahepatic bile duct [4]. This may lead to some clinical cases including obstructive icterus, fever, cholangitis, pancreatitis, and liver abscess [5].

Surgery remains the method of choice for the treatment of hydatid cysts. With surgery, clearance of parasites, sterilization of the cyst, excision of germinative membranes, and the conservation of hepatic functions are aimed [6]. The procedures in surgery include partial cystectomy, capitonage, marsupialization, unroofing, intraflexion, total or partial hepatic resection, and lobectomy [7].

The present study aims to analyze the demographic and laboratory features of the cyst and its relation with bile ducts, along with the effects of surgical procedures on morbidity and hospital stay.

\section{Materials and Methods}

The retrospective study included 100 patients who were operated on due to liver hydatid cyst at Dicle University Faculty of Medicine Department of General Surgery between March 2005 and January 2010. Age, gender, the count, location, and size of cysts, history of icterus, laboratory signs, surgical procedures performed, results of previous medical treatments, presence of intracavitary bile duct, operative 
Table 1. Demographic Data of the 100 Patients

\begin{tabular}{ll}
\hline Demographic characteristic & Value \\
\hline Age (years) & 35.6 \\
Mean & $15-80$ \\
Range & $37 / 63$ \\
Gender (Male/Female) & \\
Symptoms and signs & 95 \\
Right hypochondrial pain (\%) & 12 \\
Nausea and vomiting (\%) & 12 \\
Icterus (\%) & 8 \\
Palpable mass (\%) & 4 \\
Weakness-anorexia (\%) & 6 \\
Fever, chills (\%) & 3 \\
Abdominal distension (\%) &
\end{tabular}

complications, and length of hospital stay were recorded.

For each patient, WBC, liver and kidney function tests, posterior-anterior chest X-Ray, electrocardiography, radiological ultrasound (USG) and computed tomography (CT) were obtained. In liver function tests, values over $41 \mathrm{U} / \mathrm{L}$ for alanine aminotransferase (ALT), $37 \mathrm{U} / \mathrm{L}$ for aspartate aminotransferase (AST), $53 \mathrm{U} / \mathrm{L}$ for gamma-glutamyl transferase (GGT), $270 \mathrm{U} / \mathrm{L}$ for alkaline phosphatase (ALP), and $1 \mathrm{mg} /$ $\mathrm{dL}$ for bilirubin were regarded as high. Eosinophilia was accepted on the values of $\geq 11,000 / \mathrm{mm}^{3}$ for leukocyte $\geq 7 \%$ for eosinophilia. The Gharbi classification was used to stage the cysts [8]. In order to assess the relation of the cyst with the biliary tract, the relevant ducts were visualized following the irrigation of the cavity via isotonic after the drainage of the cyst had been achieved. Once the visible ducts were sutured, serum physiological buffers were installed into the cavity. Compression was applied to the gallbladder by the atraumatic clamping of the hepatoduedonal ligament. Periods of 5 10 minutes were allowed to check the biliary contamination in the buffers removed.

Minor complications included pleural effusion, atelectasis, and wound infection. Reported major complications were pus infection, biliary fistula, liver hematoma, gastrointestinal fistula, pneumonia, and empyema and ileus development.

Data analysis was performed with SPSS 11.5 (SPSS Inc., Chicago, IL, USA). Quantitative values were evaluated by chi-square test, while Student-t test was used for parametric data and Mann Whitney-U test for nonparametric data. The factors for hospital stay were evaluated by linear regression test. A P value of $<0.05$ was considered to be statisti- cally significant.

\section{Results}

The 100 patients comprised 63 (63\%) women and $37(37 \%)$ men, with a mean age of $35.6 \pm 15.6(15-80)$ years. Abdominal pain was the most common complaint. The physical examinations were found normal, while an icteric and palpable mass was detected as the most common finding (Table 1).

Endoscopic retrograde cholangio-pancreatography (ERCP) was used preoperatively for patients with history of cholangitis, obstructive icterus, and pancreatitis. Laboratory parameters verified leukocytosis in 24 (24\%), eosinophilia in $27(27 \%)$, alkaline phosphatase (ALP) in $23(23 \%)$, GGT in $35(35 \%)$, AST in $32(32 \%)$, ALT in $24(24 \%)$, and elevated direct bilirubin in $21(21 \%)$ patients. The total count of the cysts in 100 patients was 134 . Single cyst was present in 71 (71\%), and multiple cyst in $29(29 \%)$ patients. Right-lobe cyst was present in 82 patients $(82 \%)$, while in 62 of them the cyst was present only in the right lobe. Mean diameter of cyst was $10.15 \pm 4.17(4-30) \mathrm{cm}$. The Gharbi classification revealed type III cyst in $52(52 \%)$ patients (Table 2$)$.

Urgent operation was undertaken in 2 patients due to the intraabdominal perforation of the cyst, and the remaining 98 were operated on electively. Conservative methods including either partial cystectomy plus drainage alone or together with capitonage plus omentoplasty were performed in 88 patients, while 7 received laparoscopic intervention plus drainage and 5 underwent total excision (Table 3). In 48 patients, cysts communicating with biliary tract were detected. 
Table 2. Characteristic Features of Hepatic Hydatid Cysts

\begin{tabular}{|c|c|}
\hline Characteristic features & Value \\
\hline Total count, $\mathrm{n}$ & 134 \\
\hline \multicolumn{2}{|l|}{ Number of cysts in each patient, $n$} \\
\hline One & 71 \\
\hline Two & 26 \\
\hline Three & 1 \\
\hline$\geq$ Four & 1 \\
\hline \multicolumn{2}{|l|}{ Localization, $\mathrm{n}$} \\
\hline Right lobe & 64 \\
\hline Left lobe & 17 \\
\hline Both lobe & 17 \\
\hline Caudate lobe & 1 \\
\hline Right and caudate lobe & 1 \\
\hline \multicolumn{2}{|l|}{ Size $(\mathrm{cm})$} \\
\hline Mean & 10.15 \\
\hline Range & $4-30$ \\
\hline \multicolumn{2}{|l|}{ Gharbi morphological type of cyst, $n$} \\
\hline Type 1 & 1 \\
\hline Type 2 & 14 \\
\hline Type 3 & 52 \\
\hline Type 4 & 33 \\
\hline $\begin{array}{l}\text { Cysts detected with intraoperative relation to } \\
\text { biliary tract }\end{array}$ & 48 \\
\hline
\end{tabular}

Of these, 33 were treated with primary suturation for open ductuses, 6 with insertion of T-tube in external bile ducts, and 9 with both of them. There was no significant difference in complication rate and length of hospital stay among different surgical procedures $(\mathrm{P}>0.05)$.

It was found that the largeness and bilobular location of the cyst is statistically correlated with the rate of communication between the cyst and the biliary tract in cases with elevated AST, ALP, and GGT in the preoperative period. No significant difference was observed in minor complication rate among the patients detected with hydatid cyst and the ones with no detection; however, major complication rates and lengths of hospital stay were found significantly higher in the ones detected with the cysts associated with biliary tract (Table 4).

A total of 62 complications occurred in 43 patients.
Among these, pus infection and pulmonary complications were the most common (Fig. 1).

Among the patients with biliary fistula, the fistula of 10 patients closed spontaneously and 9 patients were inserted endoscopic sphincterotomy or stent. One patient, who did not recover despite sphincterotomy, received surgical treatment. Most of the patients with pus infection were treated with antibiotherapy or pus irrigation. Only 3 patients received USG-aided catheterization due to resistant abscess formation. Mean length of hospital stay was 12.79 (4 - 97) days. No mortality occurred pre- or post-operatively.

\section{Discussion}

Liver hydatid cyst, more common in women (51.2-77\%), is 


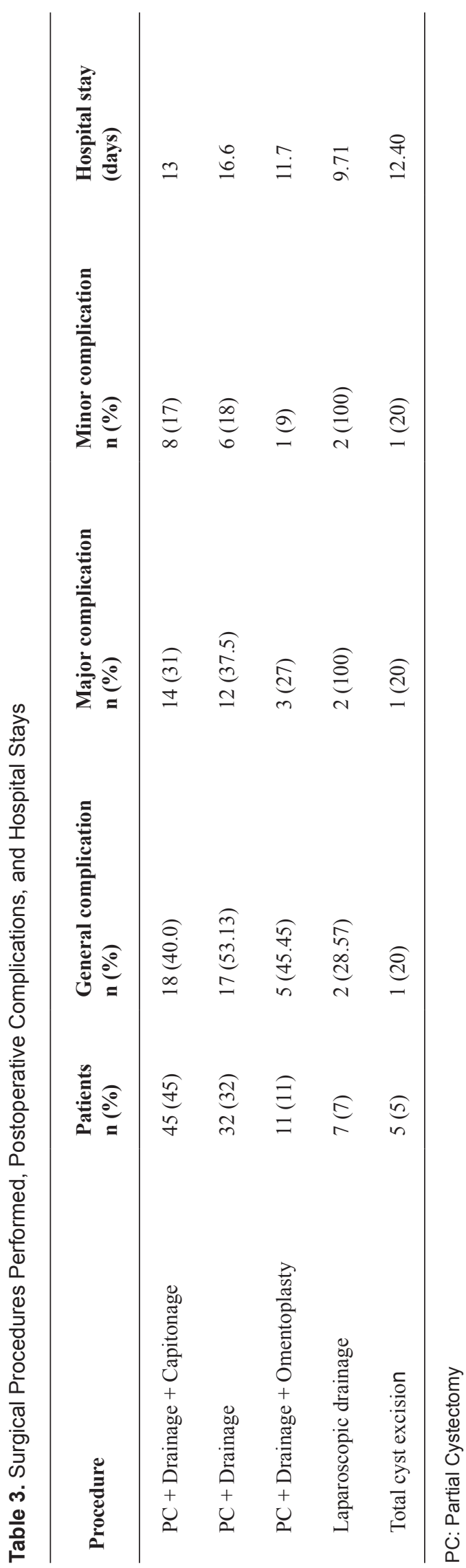

generally asymptomatic or produces minimal specific symptoms. It is most common in the third or fourth decade [4]. It is usually located in the liver since the parasite first reaches the liver via portal vein after passing the gastrointestinal system. The disease may become evident when a solitary cystic lesion is noted and it is commonly located in the right lobe of the liver [9]. The $63 \%$ of our patients were women, with a mean age of 35.6 years. Single cyst was present in $71 \%$, while right-lobe cyst was present in 82 patients $(82 \%)$, and in 62 of them the cyst was present only in the right lobe of the liver.

The disease is coincidentally diagnosed in visualisations conducted for different purposes. It is usually accompanied by the right hypochondrial pain. Common nonspecific findings include weakness, fever, dyspepsia, and nausea. In complicated cases, fever, icterus, and anaphylactic reactions are possible [10]. Şahin et al [4] reported the most common complaint as abdominal pain (77.5\%), and the most common finding as hepatomegaly ( $31.7 \%$ ), adding that $45 \%$ of the patients were asymptomatic. On the other hand, Kucuk et al [11] reported the abdominal pain in $38.4 \%$ while acknowledging the hepatomegaly as the most common symptom. We detected the abdominal pain in $95 \%$ of our patients and the most common finding in physical examination was icterus with a rate of $12 \%$. Only $8 \%$ our patients were present with palpable mass.

There have been numerous studies focusing on the relation of preoperative cyst to biliary tract by means of blood counts, biochemical parameters, and radiological findings; however, there is still no consensus on a standard method [12-16]. It is easy to assess the probability of the relation between cyst and biliary tract in cases with obvious fistulas caused by complications like cholangitis, icterus, and anaphylactic reactions; yet it is not so easy in asymptomatic cases [17]. The highness of this probability is attributed to various findings by several studies: Dogan et al [16] attribute it to elevated GGT an AFP (alpha fetoprotein), while Unalp et al [13] ascribe it to elevated levels of ALP, total bilirubin, and leukocyte count, and Demircan et al [12] assign it to elevated levels of hepatic enzymes, and presence of eosinophilia. Accordingly, the group with elevated ALP, GGT, and AST in our group had a higher rate of probability. However, the presence of eosinophilia in the same group did not present statistical significance. Also, the other variants including elevated leukocyte, bilirubin, or ALT levels did not present statistical significance, either.

Cyst rupture into the biliary tract is a common complication in hydatid cyst. It has a higher incidence rate in the cysts that are centrally located, multilocular, and larger in diameter $[14,17]$. Larger cysts are commonly reported to correlate with the cystobiliary communication $[12,13,18]$. Kiliç et al [18] evaluated 116 cases of hydatid cyst, where they proved that cysts larger than $7.5 \mathrm{~cm}$ led to an outright increase in the risk of rupture into biliary tract. The same value was reported 
Table 4. Demographic Features and Laboratory Signs of the Groups That are Detected With and Without Relation of Cystic Cavity With Biliary Tract

\begin{tabular}{|c|c|c|c|}
\hline & $\begin{array}{l}\text { Relation detected } \\
(n=48)\end{array}$ & $\begin{array}{l}\text { No relation detected } \\
(\mathrm{n}=52)\end{array}$ & P value \\
\hline Number of cysts in each patient, $\mathrm{n}(\%)$ & & & NS \\
\hline One & $36(75)$ & $35(67.3)$ & \\
\hline Two & $16(33.3)$ & $16(30.7)$ & \\
\hline Three & $0(0)$ & $1(1.7)$ & \\
\hline$\geq$ Four & $2(4.1)$ & $0(0)$ & \\
\hline Localization, $\mathrm{n}(\%)$ & & & $\mathrm{P}=0.018$ \\
\hline Right lobe & $26(54.5)$ & $38(73.5)$ & \\
\hline Left lobe & $7(14.5)$ & $10(19.3)$ & \\
\hline Both lobe & $14(29)$ & $3(5.3)$ & \\
\hline Caudate lobe & $0(0)$ & $1(1.7)$ & \\
\hline Right and caudate lobe & $1(1.9)$ & $0(0)$ & \\
\hline Size $(\mathrm{cm})$ & & & $\mathrm{P}<0.001$ \\
\hline Mean & $11.81 \pm 4.71$ & $8.61 \pm 2.87$ & \\
\hline Range & $6-30$ & $4-15$ & \\
\hline Gharbi morphological type of cyst, $n$ & & & NS \\
\hline Type 1 & $1(2)$ & $0(0)$ & \\
\hline Type 2 & $7(14.5)$ & $7(14)$ & \\
\hline Type 3 & $28(58.5)$ & $24(46)$ & \\
\hline Type 4 & $12(25)$ & $21(40)$ & \\
\hline Serum ALT level & 61.69 & 64.75 & NS \\
\hline Serum AST level & 75.19 & 69.70 & $\mathrm{P}=0.042$ \\
\hline Serum ALP level & 162.56 & 124.38 & $\mathrm{P}=0.022$ \\
\hline Serum GGT level & 196.15 & 114.48 & $\mathrm{P}=0.030$ \\
\hline Total bilirubin & 1.97 & 1.11 & NS \\
\hline Direct bilirubin & 1.29 & 0.52 & NS \\
\hline WBC & 9.645 & 9.056 & NS \\
\hline Eosinophilia & $17(37.7)$ & $10(19.2)$ & NS \\
\hline ERCP & $8(16.7)$ & $5(9.6)$ & NS \\
\hline Icterus, $\mathrm{n}(\%)$ & $8(16.7)$ & $4(7.7)$ & NS \\
\hline Minor complications & $10(20.8)$ & $9(17.3)$ & NS \\
\hline Major complications & $24(50)$ & $8(15.4)$ & $\mathrm{P}<0.001$ \\
\hline Hospital stay (days) & 17.48 & 8.46 & $\mathrm{P}<0.001$ \\
\hline
\end{tabular}

NS: Not Significant 


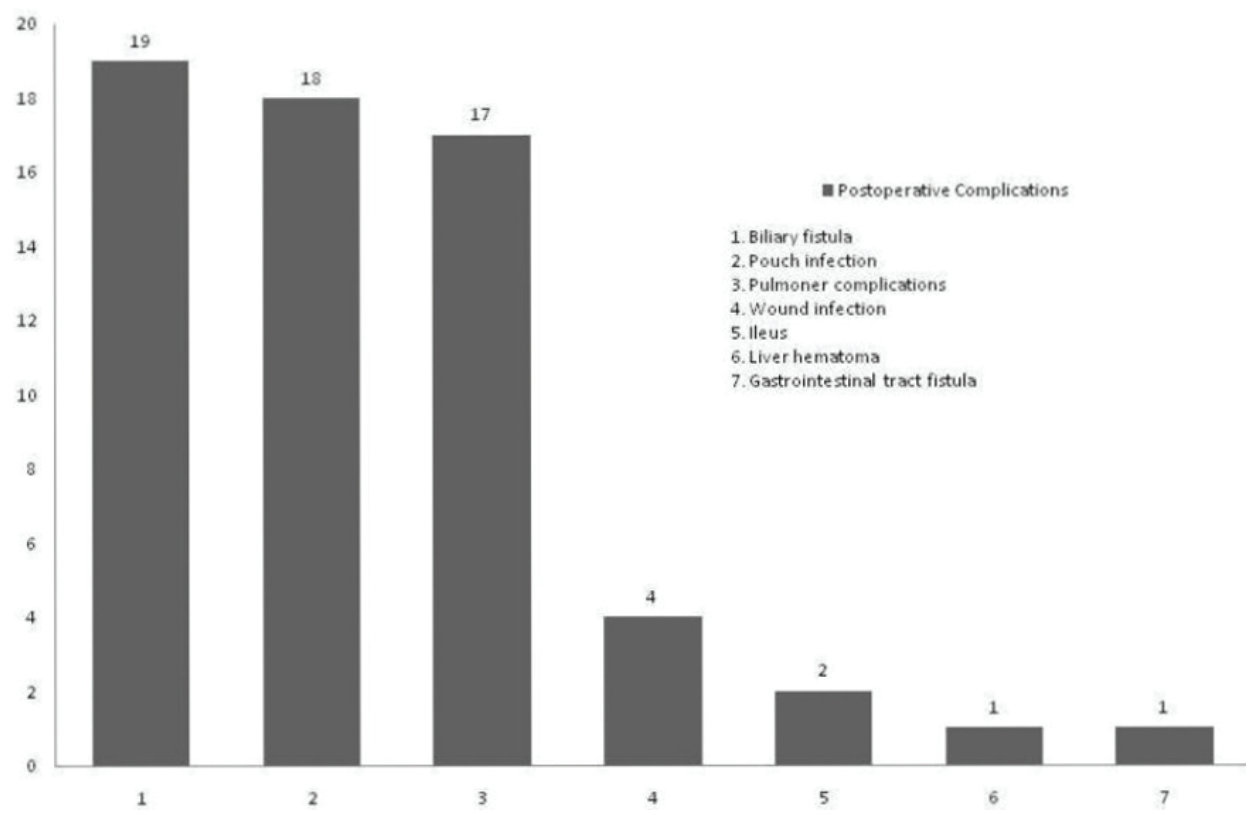

Figure 1. Postoperative complications.

as $8.5 \mathrm{~cm}$ in another study [12]. Unalp et al [13] studied 183 cases of occult and asymptomatic type and reported that the cysts larger than $10 \mathrm{~cm}$ are predictive for postoperative biliary fistula. Mean diameter of cyst was $11.8 \mathrm{~cm}$ in the group with intraoperative relation to biliary tract, while in the other group it was $8.6 \mathrm{~cm}$. In addition, the probability rate of the relation with biliary tract was higher in the patients present with cysts on both lobes.

Demircan et al [12] assessed differences both in complication rates and hospital stays in the groups with and without associated cysts as $53.7 \%$ and $10 \%$ and 14.3 days and 7.3 days, respectively. Another study reported the hospital stay for both groups as 7 days and 14 days, respectively [19]. Cysts communicating with biliary tract were detected in 48 patients in our study, who had a complication rate of $50 \%$ and a hospital stay of 17.8 days. The other group with no association had $15.4 \%$ and 8.4 days, respectively. The communication between cyst and biliary tract is statistically correlated with the rate of major complications (biliary fistula in particular) and with hospital stay.

The intra-cystic pressure is higher than the intraluminal pressure of the bile duct, which makes the bile flow go through the cyst to the biliary tract. In postoperative period the pressure of the cystic cavity gets lower, and the bile flow in patients with intraoperative biliary contamination may turn into the cystic cavity [14]. Postoperative fistula may constitute $2.6 \%$ to $28.6 \%$ of all complications. Kayaalp et al [19] evaluated that the biliary leakage occurred at a rate of $26 \%$ and $9.3 \%$ of them developed biliary fistula, adding that $64 \%$ of biliary leakages closed spontaneously. Biliary leakage was evident in $19(19 \%)$ of our patients, while 9 of them developed biliary fistula. Of the ones with biliary leakage,
$52.6 \%$ of them closed spontaneously.

Conservative surgeries remain the most common methods used in the treatment of cyst hydatid. In choosing the ideal surgical method, the organ in which the cyst is located and anatomical location of the cyst, the count, size, and type of the cyst along with its relation to other anatomical structures, and complications including accompanying infection, and rupture into biliary tract are taken into consideration [4]. No statistical association was reported between the surgical procedures performed and the complication rate in relevant studies $[4,9,11,20]$. Also, Bulbuller et al [20] revealed that the surgical procedures are not correlated with recurrence development. Most of our patients received conservative surgery $(88 \%)$, and the most commonly used technique was partial cystectomy + drainage + capitonage $(45 \%)$.

In addition, there was no correlation between the surgical procedures performed and the complication rate, as consistent with the literature.

For surgical treatment of cyst hydatid patients with spontaneous rupture into intrahepatic bile duct, the removal of the cystic residues in the biliary tract through exploration of the choledoch plus choledochal drainage via T-tube is recommended as an alternative for bilioenteric anastomoses [21]. However, widespread usage of ERCP in current procedures enabled lower mortality and proper treatment of the disease as well. ERCP is an effective method in cyst hydatid cases for the diagnosis and treatment of complications including cholangitis, obstructive icterus and pancreatitis caused by rupture into biliary tract, and for the treatment of postoperative biliary fistulas [4]. ERCP was performed in 13 of our patients due to obstructive icterus or cholangitis. Choledochal exploration plus T-tube was performed in 15 patients who 
were present with dilatation in the intraoperative biliary tract or had an over $5 \mathrm{~cm}$ biliary tract. No bilioenteric anastomosis was performed in our study. Endoscopic sphincterotomy was applied in a total of 9 patients: 4 of them were the patients that received T-tube and had biliary fistula for more than ten days after being inserted intracavitary drainage, while 2 of them were present with intraoperative biliary tract and 3 of them without; in 8 of them the fistula closed spontaneously with no need for surgical intervention.

Postoperative complications including liver hematoma, intraabdominal infection or abscess, cystic cavity infection, biliary fistula, and surgical site infection constitute $8 \%$ to $80 \%$ of all cases [9]. The most common complication reported by Kucuk et al [11] and Albayrak et al [7] was biliary fistula with the rates of $3.2 \%$ and $18 \%$, respectively, while wound infection was the most common one in the study by Şahin et al [4] with a rate of $12.8 \%$. In our study, biliary fistula was the most common one $(19 \%)$, which was followed by cystic cavity infection, pulmonary complications, and wound infection.

Presence of biliary fistula is the most important factor that prolongs the length of postoperative hospital stay [12, 22]. Kayaalp et al [19] report that this prolonging may be up to 6 - 17 days. In another study, mean hospital stay was 7.3 days for the group with no biliary fistula and 14.3 days for the group with fistula [12]. In our study, major reasons for longer hospital stays included the relation of cyst to biliary tract and postoperative biliary fistula. Additionally, pus infection $(18 \%)$ was also effective on longer hospital stays in our series. Among the patients with pus infection, 6 of them had accompanying biliary fistula, and their mean hospital stay was 24.7 days.

\section{Conclusion}

Intrabiliary rupture of the cyst is correlated with complication rate and hospital stay. Higher values of preoperative ALP, GGT, and AST, and larger cysts with bilobular location increase the statistical risk of intrabiliary rupture of the cyst. We conclude that there was no significant difference in complication and recurrence rates among different surgical procedures; hence in endemic regions, radical surgeries should only be implemented for selected cases.

\section{References}

1. Kammerer WS, Schantz PM. Echinococcal disease. Infect Dis Clin North Am. 1993;7(3):605-618.

2. Ezer A, Nursal TZ, Moray G, Yildirim S, Karakayali F, Noyan T, Haberal M. Surgical treatment of liver hydatid cysts. HPB (Oxford). 2006;8(1):38-42.

3. Eckert J, Deplazes P. Biological, epidemiological, and clinical aspects of echinococcosis, a zoonosis of increas- ing concern. Clin Microbiol Rev. 2004;17(1):107-135.

4. Şahin EM, Yüksek YN, Dağlar G, et al. Diagnosis and Treatment of Hydatid Cysts: Results of 120 patients. Medical Journal of Trakya University. 2008; 25:6-14.

5. Ödev K, Paksoy Y, Kıreşi DA. Travmaya bağlı rüptüre karaciğer kist hidatik kisti. TRD. 1998; 33:657-9.

6. Youssef F, Mahfoud B, Bilal M. The Management Of Liver Hydatid Cyst Disease With Aconservativa Surg. 1998; 45:126.

7. Albayrak D, Sezer YA, İbiş AC, et al. Hepatic Hydatid Cyst Cases. Medical Journal of Trakya University. 2008; 25:95-99.

8. Gharbi HA, Hassine W, Brauner MW, Dupuch K. Ultrasound examination of the hydatic liver. Radiology. 1981;139(2):459-463.

9. Şahin DA, Kuşaslan R, Türel KS, Akbulut G, Arıkan Y, Dilek ON. Karaciğer kist hidatik olgularımızda cerrahi tedavi ve ERCP ile sfinkterektominin etkinliği. Kocatepe Tip Dergisi. 2006; 7:11-16.

10. Milicevic M, Saidi F, Sayek İ. Karaciğer kist hidatiği. In: Sayek İ,editör. Temel Cerrahi.3rd ed.Ankara: Güneş Tip Evi;2004.s.1317-1324.

11. Küçük C,Yılmaz N, Akyıldız H, Sözüer E. Surgical treatment in liver cyst hydatid cases: Analysis of 276 patients. Erciyes T1p Dergisi, 2008; 30:170-4.

12. Demircan O, Baymus M, Seydaoglu G, Akinoglu A, Sakman G. Occult cystobiliary communication presenting as postoperative biliary leakage after hydatid liver surgery: are there significant preoperative clinical predictors? Can J Surg. 2006;49(3):177-184.

13. Unalp HR, Baydar B, Kamer E, Yilmaz Y, Issever H, Tarcan E. Asymptomatic occult cysto-biliary communication without bile into cavity of the liver hydatid cyst: a pitfall in conservative surgery. Int J Surg. 2009;7(4):387-391.

14. Yüksel O, Akyürek N, Bostancı H, Şahin T, Azıll C, Aydın A. Karaciğer kist hidatiğinde okült kisto-biliyer ilişkinin gösterilmesinde metilen mavisinin etkinliği. Ulusal Cerrahi Dergisi. 2007; 27:19-23.

15. Doğan R, Yıldız F, Çoban S, Terzi A,Aksoy N,Uzunköy A. Karaciğer kist hidatiği hastalığında kistin safra yolları ile ilişkisini belirlemede tümör markırları ve biyokimyasal değerlerin katkısı. Harran Üni. Tıp Fakültesi Dergisi. 2009; 6:40-42.

16. El Malki HO, El Mejdoubi Y, Souadka A, Mohsine R, Ifrine L, Abouqal R, Belkouchi A. Predictive model of biliocystic communication in liver hydatid cysts using classification and regression tree analysis. BMC Surg. 2010;10:16.

17. Erzurumlu K, Dervisoglu A, Polat C, Senyurek G, Yetim I, Hokelek M. Intrabiliary rupture: an algorithm in the treatment of controversial complication of hepatic hydatidosis. World J Gastroenterol. 2005;11(16):2472-2476.

18. Kilic M, Yoldas O, Koc M, Keskek M, Karakose N, Er$\tan \mathrm{T}$, Gocmen E, et al. Can biliary-cyst communication 
be predicted before surgery for hepatic hydatid disease: does size matter? Am J Surg. 2008;196(5):732-735.

19. Kayaalp C, Bzeizi K, Demirbag AE, Akoglu M. Biliary complications after hydatid liver surgery: incidence and risk factors. J Gastrointest Surg. 2002;6(5):706-712.

20. Bulbuller N, Ilhan YS, Kirkil C, Yenicerioglu A, Ayten $\mathrm{R}$, Cetinkaya $\mathrm{Z}$. The results of surgical treatment for hepatic hydatid cysts in an endemic area. Turk J Gastroen- terol. 2006;17(4):273-278.

21. Bedirli A, Sakrak O, Sozuer EM, Kerek M, Ince O. Surgical management of spontaneous intrabiliary rupture of hydatid liver cysts. Surg Today. 2002;32(7):594-597.

22. Kayaalp C, Bostanci B, Yol S, Akoglu M. Distribution of hydatid cysts into the liver with reference to cystobiliary communications and cavity-related complications. Am J Surg. 2003;185(2):175-179. 